\title{
The influence of habitat on the spatio-temporal dynamics of fish assemblages in a lagoon-estuarine system of the Mexican Pacific
}

\author{
Emilio I. Romero-Berny ${ }^{1}$, Ernesto Velázquez-Velázquez ${ }^{2}$ \\ Juan J. Schmitter-Soto ${ }^{3}$ \& Isaías H. Salgado-Ugarte ${ }^{4}$ \\ ${ }^{1}$ Centro de Investigaciones Costeras, Instituto de Ciencias Biológicas \\ Universidad de Ciencias y Artes de Chiapas, Tonalá, Chiapas, Mexico \\ ${ }^{2}$ Museo de Zoología, Instituto de Ciencias Biológicas \\ Universidad de Ciencias y Artes de Chiapas, Chiapas, Mexico \\ ${ }^{3}$ Departamento de Sistemática y Ecología Acuática, El Colegio de la Frontera Sur \\ Chetumal, Quintana Roo, Mexico \\ ${ }^{4}$ Laboratorio de Biometría y Biología Pesquera, Facultad de Estudios Superiores Zaragoza \\ Universidad Nacional Autónoma de México, Iztapalapa, Mexico City, Mexico \\ Corresponding author: Emilio I. Romero-Berny (emilio.romero@unicach.mx)
}

\begin{abstract}
Fish assemblages change significantly with physical and chemical characteristics of water; however, their response to the variability of geomorphic habitats has been rarely evaluated in lagoon-estuarine in one of these systems of the Mexican Pacific. Spatio-temporal variation of fish assemblage structure was assessed for three habitats: lagoon, estuarine, channel and inlet. The hypothesis was that sheltered areas support comparatively higher richness and abundance of fish species, with more small-sized specimens than the most exposed areas. We found that the ichthyofauna differed significantly among habitats. Several species were smaller in the lagoon compared with the other habitats, suggesting a use of the lagoon as a nursery ground. Moreover, dominant species for the lagoon were rarely found or absent in the inlet, whereas others were found only present or with higher abundance in the inlet. Although seasonal differences in richness and composition were detected, the evidence of fish-habitat associations for many species was noticeable regardless of seasonality, probably due to a high percentage of resident species during the annual cycle. The lagoon supports a greater abundance and species richness, due to a more sheltered and structured habitat, evidencing habitat-driven segregation in fish assemblages, and an aspect that should be incorporated for management of coastal ecosystems.
\end{abstract}

Keywords: coastal; geoforms; habitat structure; ichthyofauna; nursery; Gulf of Tehuantepec

\section{INTRODUCTION}

Lagoon-estuarine systems are formed by a complex matrix of intertidal habitats with distinctive environmental features that play an essential role in support of high fish production (McLusky \& Elliott, 2004; YáñezArancibia et al., 2004; França et al., 2012). In these systems, geomorphological processes originate geoforms (e.g., lagoons, mouths and channels), which are habitats with different physical attributes (e.g., depth, width, substrate) that influence the patterns of composition, richness, abundance, migration and the size-specific spatial use by organisms (Bartholomew et al., 2000; Saintilan, 2004; Franco et al., 2006; França et al., 2009;
Hicks et al., 2010). For example, the mouth and its tidal channels are ecotones connecting the marine with the brackish environment (Webster, 2011; Lacerda et al., 2014). Furthermore, other geoforms such as lagoons, which are partially enclosed areas with low water circulation and more structural complexity (e.g., muddy bottoms, riverine and submerged vegetation), are reported as critical habitat for juvenile fish feeding and nurseries (Neves et al., 2013; Verdiell-Cubedo et al., 2013).

Habitat features have been integrated in estuarine fish research as a key factor to understand the structure of ecological assemblages and their relationship with highly variable spatial conditions and allows to define

Corresponding editor: Yassir Torres 
connectivity mechanisms between habitats and local migration patterns (Sindilariu et al., 2006; Franco et al., 2009; Neves et al., 2011), as has been shown by several studies carried out in estuaries and coastal lagoons of Europe, South Africa, Australia and South America (Patterson \& Whitfield, 2000; Griffiths, 2001; Franco et al., 2006; Neves et al., 2011; Loureiro et al., 2016).

Some studies have been conducted on fish assemblages of Mexican coasts, concerning mainly lagoonestuarine systems from the Gulf of Mexico and the northwest and central Pacific areas (Warburton, 1978; Mendoza et al., 2009; Castillo-Rivera et al., 2010; Rodríguez-Romero et al., 2011; Ayala-Pérez et al., 2014). These studies indicate that physical and chemical changes (e.g., variations in salinity, water temperature, turbidity, dissolved oxygen, etc.) associated with seasonality constitute a significant driver of fish assemblage patterns. However, in the south Pacific of Mexico there are no studies that include the effect of habitat complexity on fish assemblages.

The Gulf of Tehuantepec in the Mexican Southern Pacific is one of the most important fishing areas (Bakun et al., 1999; Ortega-García et al., 2000; Wilkinson et al., 2009). This region has an extensive belt of lagoon-estuarine systems surrounded by mangroves that shelters one of the richest areas for fish fauna in the Tropical Mexican Pacific (GómezGonzález et al., 2012; González-Acosta et al., 2017). The environmental differences between the geomorphic habitats that integrate these systems make them good models to test the spatial effect of its characteristics on biotic assemblages.

The rapid degradation and loss of coastal ecosystems in recent decades has increased interest in fish research and their habitat in estuarine environments (França et al., 2012; Sundblad \& Bergström, 2014). The knowledge of geomorphic habitats and their effect on fish assemblages constitutes an important baseline for the development of monitoring programs and integrate ecosystem-based management of coastal resources (Pérez-Ruzafa et al., 2007; Franco et al., 2009; Sheaves et al., 2012). Therefore, the specific aims of this study were to i) determine the spatiotemporal variations of fish assemblages in a shallow lagoon-estuarine system and compare its structure in three geomorphic habitats (lagoon, channel, inlet); and to ii) determine their relationships with hydrological parameters (e.g., salinity, dissolved oxygen, depth) and physical attributes (substrate, vegetation, shelter). The tested hypothesis is that fish assemblages are likely to differ among these habitats, with the most complex areas supporting comparatively higher fish abundance, richness and a higher number of small-sized organisms compared to less complex areas, along spatial and seasonal gradients.

\section{MATERIALS AND METHODS}

\section{Study area}

La Joya-Buenavista lagoon-estuarine system (LJB) is located at the northeastern corner of Gulf of Tehuantepec, southwest Chiapas, Mexico (15⒋' $-15^{\circ} 56^{\prime} \mathrm{N}, 93^{\circ} 32^{\prime}$ $93^{\circ} 47^{\prime} \mathrm{W}$ ); it is a shallow water body with an area of $47.5 \mathrm{~km}^{2}$ (Fig. 1). The LJB presents a sandy barrier and tides predominantly semidiurnal, with a range of $1.2 \mathrm{~m}$ (Lankford, 1977; Contreras, 2010). The water circulation into the system is reduced and depends mainly on the tides and the seasonal freshwater input provided by a few streams. The climate in this area is characterized by a dry season (November-April) and a rainy season (May-October), with a total annual rainfall of 1,441 $\mathrm{mm}$ and an average temperature of $28^{\circ} \mathrm{C}$. The salinity can vary drastically in some areas, from oligohaline (salinity <5) at the peak of the rains to hyperhaline (salinity >40) in highly protected sites during the dry season (Contreras \& Zabalegui, 1991).

This study analyzed the fish assemblages of three geomorphic habitats in the LJB system: lagoon, channel and inlet (Fig. 1). These habitats were identified mainly based on the qualitative description of physical and morphological characteristics. The depth of the lagoon varies from 0.2 to $1.5 \mathrm{~m}$, with a predominantly muddy substrate, with sparse submerged tree trunks and margins comprised of grass and

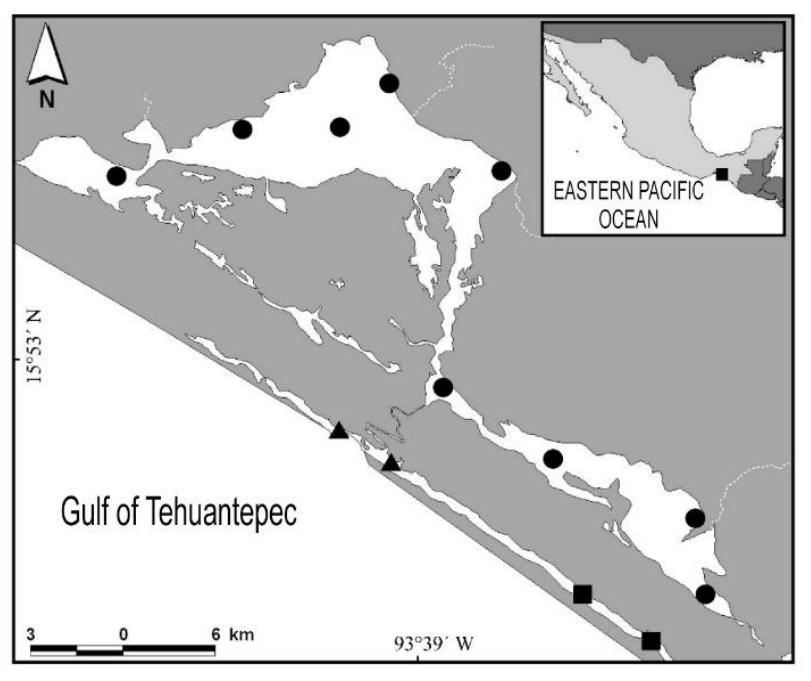

Figure 1. Map of the study area in the La Joya-Buenavista lagoon-estuarine system, Mexico. Symbols represent sampling sites coded by habitat type. Circles: lagoon, squares: channel, triangles: inlet. 
fringe/basin mangroves (Avicennia germinans L. and Conocarpus erectus L.). The channel has a total length of $23 \mathrm{~km}$ and varies in width from about $570 \mathrm{~m}$ at the mouth to $200 \mathrm{~m}$ at the head. Most of the channel zone is surrounded by riverine mangroves (Rhizophora mangle L.). Substrate composition changes from muddy, with some sandy patches in the channel, to predominantly sandy in the mouth. The inlet flows into the Gulf of Tehuantepec through an estuary mouth of $157 \mathrm{~m}$ of width, the zone most exposed to tidal currents.

\section{Data collection}

Sampling was performed bimonthly from 9:00 to 16:00 h, at 13 sites during June 2013-April 2014. Sampling was conducted using monofilament cast nets $(4 \mathrm{~m}$ diameter with $1.27 \mathrm{~cm}$ mesh). This gear could be used in all sites under its temporal variations in depth and habitat conditions, although an a priori characterization focused on small and juvenile components was assumed (Sheaves et al., 2007; Stein III et al., 2014). The cast net was operated from the shoreline or a boat by the same individual. Sampling effort was standardized to 10 cast nets. This number of deployments was determined by estimating the values of the asymptotes of plot-based species accumulation curves for each habitat in three pilot sites $\left(\mathrm{R}^{2}=0.99,0.94,0.96\right)$. Cast net deployments were done in a radius of up to $50 \mathrm{~m}$, thus avoiding the disturbance effect of three castings at the same point.

The fish specimens were weighed, measured, fixed in $10 \%$ formalin, washed in tap water after $48 \mathrm{~h}$, and transferred to $70 \%$ ethanol. All fish were identified to species and counted. Scientific names and authorities were corroborated following Fricke et al. (2019). Voucher specimens were deposited at the ichthyological collection of the Museum of Zoology of the University of Science and Arts of Chiapas (MZ-PUNICACH) in Tuxtla Gutiérrez, Mexico. For descriptive purposes, selected dominant species were allocated to four ecological categories according to their salinity tolerance (Myers, 1966; Castro-Aguirre et al., 1999; Day Jr. et al., 2012). These species were also allocated to functional guilds according to their trophic group following the criteria of Elliott et al. (2007), with information from Froese \& Pauly (2016). Four ecological groups were identified in this study: estuarine (fish that are residents in brackish waters), marine euryhaline (can tolerate a wide range of salinity), marine stenohaline (can tolerate a narrow range of salinity) and secondary freshwater (salttolerant inland fish). Likewise, five trophic groups were identified: piscivores, which are species whose diet consists mainly of fish; zooplanktivores, species that feed predominantly on zooplankton; zoobenthivores, species that feed on bottom invertebrates; detritivores, species that feed on the bottom, selecting fine particles, benthic diatoms, meiofauna and sediments; and omnivores, which feed on algae and a variety of invertebrates.

Hydrological variables were measured on each sampling event before the fish collection. Salinity, water temperature $\left({ }^{\circ} \mathrm{C}\right)$, dissolved oxygen $\left(\mathrm{mg} \mathrm{L}^{-1}\right)$, and $\mathrm{pH}$ were determined at the mid-depth of each site using a multiprobe meter (YSI 556). The depth (to the nearest $0.1 \mathrm{~m}$ ) and water clarity (Secchi's depth in $\mathrm{cm}$ ) were also determined.

Habitat structure descriptors (substrate, vegetation and shelter) were examined in the system (in this study, habitat structure was considered as the physical attributes that may provide protection and food for fish species; Green et al., 2012). At each site, a plot of $1 \mathrm{~m}^{2}$ was randomly positioned to visually evaluate the substrate composition as the percentage covered by muddy, sandy or mixed deposits. The presence of other physical elements as tree trunks and riprap was also recorded. Values for vegetation were assigned based on the dominant marginal coverage ( $>60 \%$ of mangroves or grasses) in a $200 \mathrm{~m}^{2}$ area adjacent to the sampling site. The shelter was assessed according to the distance of the sites with the inlet or the channel. Following Neves et al. (2013), each habitat attribute was assigned a value from 1 to 3 to qualify structure, and these were added to achieve a total score, estimated to obtain the overall degree of physical habitat structure. Each site was categorized with ranges from 3 (lowest habitat structure) to 9 (highest habitat structure). For example, highly exposed sites (such as the mouth) with bare sand substrate and lacking plant (e.g., grasses) or physical structures were qualified with a value of 3 , whereas other sites sheltered from the currents (such as the lagoon), with a combination of muddy substrate, submerged trunks and coverage dominated by mangroves would get a score of 9 .

\section{Data analysis}

The species dominance was determined using the Importance Value Index (IV), estimated as a percentage of the numerical abundance, biomass and frequency of all species (Krebs, 1999). We considered species that, in total, had $75 \%$ of the IV as dominant (PeraltaMeixueiro \& Vega-Cendejas, 2011).

The abundance data were fourth-root transformed to minimize the influence of overly abundant taxa. The data set was divided by the three geomorphic habitats (lagoon, nine sites, inlet and channel, two sites each; Fig. 1) and months were summarized in seasons as prewet (June), wet (August-October), pre-dry (December) and dry (February-April). An individual-based rarefac- 
tion method was used to estimate the expected number of species in a sample $[\mathrm{E}(\mathrm{S} n)]$ and calculate an abundance-corrected dataset to compensate for differences in sampling effort between habitats and seasons. The $\mathrm{E}(\mathrm{S})$ was generated for a constant number in a random set of $m$ individuals from the reference sample $(m<n)$ (Colwell et al., 2012). The variation of the rarefied species richness, as well as that of the environmental parameters between habitat and season, were analyzed using one-way analysis of variance (ANOVA), having verified the assumptions of normality and homogeneity of variances. Non-parametric ANOVA (Kruskal-Wallis test) was used in cases where heteroscedasticity was found even after the logarithmic transformation of data. A Bonferroni test (or MannWhitney pairwise to non-parametric test) followed the ANOVA procedures every time that the null hypothesis was rejected at $\alpha=0.05$ (Zar, 2010).

Non-parametric multivariate analyses were conducted to assess the spatio-temporal changes in fish assemblage structure (species composition and abundance) and their relationship to environmental parameters, after evaluating the homogeneity of the multivariate dispersion (PERMDISP) (Anderson, 2006). Preliminarily, a permutational multivariate analysis of variance (PERMANOVA) (Anderson, 2001), conducted on a Euclidean similarity matrix of all environmental data, assessed differences, and the interaction between habitats and seasons. Furthermore, principal component analysis (PCA) was performed on the normalized hydrological data $(\log x+10)$ to explore gradients in the sampling events. To avoid bias in the PCA related to highly correlated hydrological data, before PCA, a Pearson correlation test was performed, and variables that show high collinearity $(r>8)$ were not considered in this analysis. Later, differences in fish assemblages between habitat and seasons were also assessed by PERMANOVA, including habitat type (fixed factor), seasons (fixed factor), sampling sites (nested in habitat type) and months (nested in seasons), conducted on a Bray-Curtis similarity matrix. A pairwise post-hoc comparison was performed, while results off that PERMANOVA were significant.

The similarity percentage analysis (SIMPER) (Clarke, 1993) was used to describe the variance explained per species by habitat. Standard length (SL) data of dominant species selected by SIMPER were compared with a Kruskal-Wallis test and the MannWhitney pairwise test to assess possible variations in the size of individuals per habitat.

Finally, distance-based linear modelling (DistLM) (Anderson et al., 2008) with a step-wise procedure and an adjusted $R^{2}$ selection criterion (Legendre \& Anderson, 1999), was performed on the fourth-root abundance matrix and the normalized environmental data (including habitat structure values). The resulting model was represented in a multi-dimensional space with a distance-based redundancy analysis (dbRDA) (McArdle \& Anderson, 2001), to assess the relative contributions of environmental variables in structuring fish assemblage and detect a possible spatial gradient. We worked with a 5\% significance level $(P \leq 0.05)$ in all statistical tests. All multivariate analyses were performed with routines in PERMANOVA+ for PRIMER 6 software (Clarke \& Gorley, 2006; Anderson et al., 2008). All other analyses were carried out with package Vegan in language R, version 3.1.2 (Oksanen et al., 2014; R Development Core Team, 2014).

\section{RESULTS}

\section{Environmental variation}

The PERMANOVA results showed that hydrological variables were significantly different between habitats $(F=9.25, P<0.01)$, seasons $(F=18.98, P<0.01)$ and the interaction (habitat $\times$ season, $F=4.69, P<0.01$ ). Likewise, differences in some hydrological parameters were consistent $(P<0.05)$ between seasons and habitats, or both. In paired comparisons within temporal factor, major differences between habitats were observed in all seasons $(P<0.02)$, except for the inlet-channel pair; oxygen saturation was low during the dry season in the channel (1 $\mathrm{mg} \mathrm{L}^{-1}$; April), while higher concentrations were for the lagoon (5.3-9.5 mg $\mathrm{L}^{-1}$ ) in the wet and pre-dry seasons. According to an adaptation of the Venice system used to describe salinity zones in estuaries (Whitfield, 1998), the inlet and channel areas are typically polyhaline, ranging from 22.1 to 29.5 , whereas the lagoon was significantly different from mesohaline conditions (13). Seasonal variations in salinity were recorded, ranging from oligohaline (wet season; 3.3 ) to marine conditions (dry; 34.1). Water temperature and $\mathrm{pH}$ presented seasonal variations, while the depth and water clarity only showed changes between habitats. The habitat structure score presented its highest mean value for the lagoon (8.6), while the lowest value was obtained for the inlet (3.3) (Table 1).

The PCA of the hydrological variables explained $63.6 \%$ of the variance for the first two axes (Fig. 2). This model considered only four explanatory variables after reducing multicollinearity. The PC1 contributed with $36.8 \%$ of the explained variance and it was strongly related (based on eigenvectors of correlation matrix) with depth (-0.56) and salinity $(-0.45)$; whereas, the PC2 contributed with $26.8 \%$ of the explained variance and better correlated with dissolved oxygen $(0.43)$ and $\mathrm{pH}(-0.41)$. 
Table 1. Means (and standard deviation) of hydrological parameters in the La Joya-Buenavista lagoon-estuarine system (Mexico), June 2013-April 2014, and results of the ANOVA $(F)$ and Kruskal-Wallis test $(H)$ analyses for spatial and temporal comparisons for each parameter. Significant $P$-values $(<0.05)$ are in bold. Seasons having the same superscript letter were not significantly different within each temporality. Habitat structure values also are presented. I: inlet; C: channel; L: lagoon.

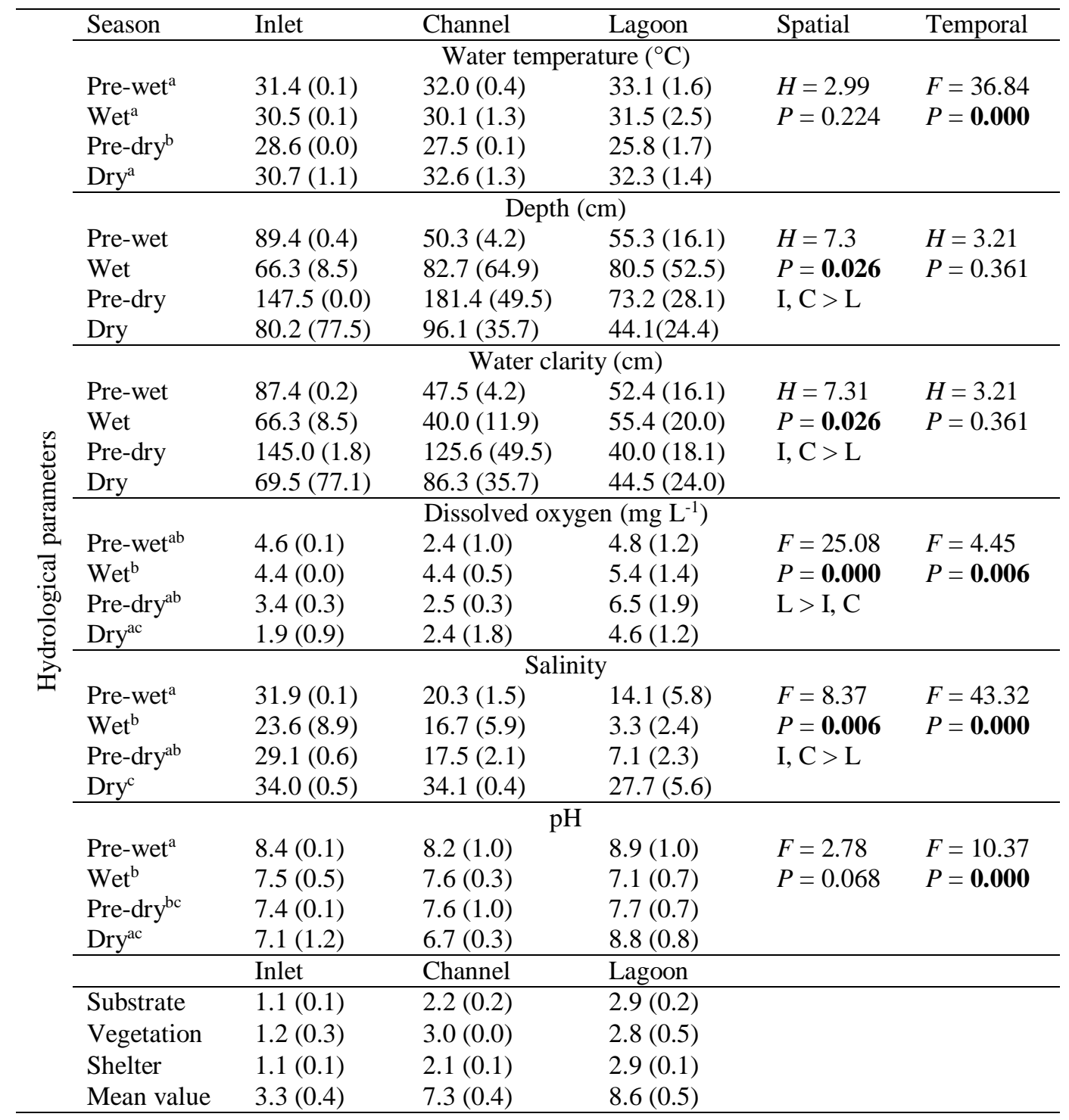

\section{Fish assemblage structure}

Two thousand sixty-four fish individuals were collected by cast net (from 76 sampling events during the study period) and were identified in 48 species and 21 families. The fish assemblage in the LJB was dominated by Lile gracilis (13.91\%), followed by Astatheros macracanthus (10.08\%) and Eucinostomus currani (9.98\%); only three species, Mugil curema, Dormitator latifrons and Gerres simillimus contributed with an amount as large as $36.78 \%$ of the total biomass.
According to the IV, 15 species together contribute $75 \%$ of relative value (Table 2 ).

Although the LJB system showed a significant environmental variation between seasons, the fish fauna exhibited their main variations across habitat types. The observed number of species per habitat was 35 in the lagoon, 20 in the inlet and 17 in the channel. Significant differences were found between habitat with the standardized richness [E $\left.\left(\mathrm{S}_{1251}\right)\right]$, ranging from 13 taxa (channel) to 26 taxa (lagoon) $(H=6.98, P<$ 


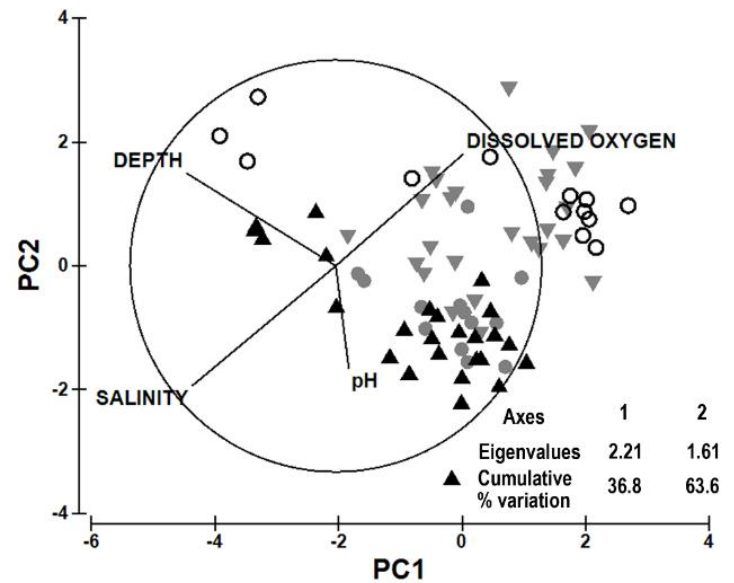

Figure 2. Principal component analysis environmental biplot, La Joya-Buenavista lagoon-estuarine system, Mexico. The length and direction of the vectors represent the strength of the relationship concerning a unit circle. Symbols represent an individual sampling event coded by season. Gray circles: pre-wet, gray inverted triangles: wet, white circles: pre-dry, black triangles: dry.

0.05) (Fig. 3a). Differences were found between seasons with the $\mathrm{E}\left(\mathrm{S}_{710}\right)$, ranging from 20 taxa (prewet) to 33 taxa (pre-dry), although these were not significant $(F=1.7, P>0.05)$ (Fig. 3b).

\section{Spatial and temporal variation of fish assemblages}

The PERMANOVA results conducted showed that fish assemblages differed significantly at the spatial level (habitat, sampling site; $P<0.01$ ). At the temporal level, differences between seasons were also detected, but not by month or their interactions (Table 3 ).

According to the SIMPER analysis, the average dissimilarity among habitats ranged from 88.3 to $97.3 \%$. Most of the dissimilarity between lagoon-inlet and inlet-channel was due to the species E. currani (14.7 and $16 \%$, respectively), while Centropomus robalito presented a high contribution $(12.8 \%)$ in the dissimilarity between the lagoon and channel (Table 4). Regarding the functional guilds in the mouth and lagoon, euryhaline species $(\bar{X}=61.8 \% \pm 29.3)$ and omnivores $(\bar{X}=58.8 \% \pm 30.9)$ were dominant in abundance, while estuarine residents (53.8\%) and zooplanktivores $(44.1 \%)$ were more abundant in the channel.

The mean fish size differed among the three habitats $(H=62.26, P<0.01)$. Standard length data showed that some of the dominant taxa (A. macracanthus, $M$. curema, E. currani, D. latifrons) were smaller in the lagoon compared with other habitats according to the Mann-Whitney test. In the case of Lutjanus argentiventris, which was not captured in the lagoon, the smaller specimens corresponded to the inlet. On the
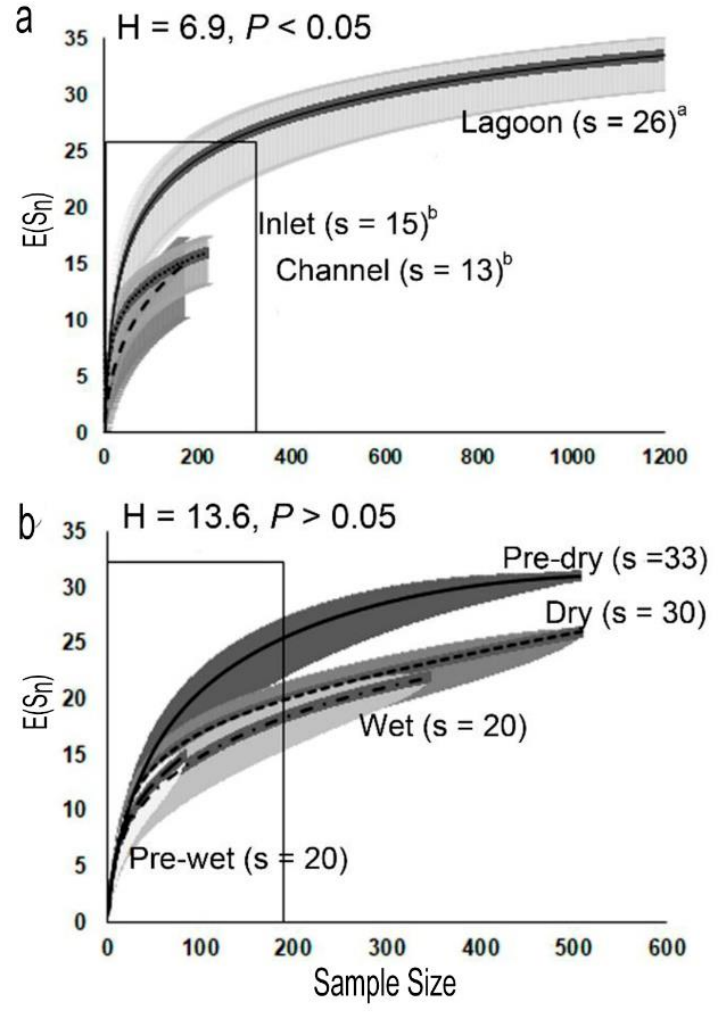

Figure 3. Rarefaction curves of the expected number of species as a function of sample size calculated by a) habitat and b) season; La Joya-Buenavista lagoon-estuarine system, Mexico. The bars indicate the subsample limits for the number of species and specimens. For the standardized richness values sharing the same letter were not statistically different at $P<0.05$ with the non-parametric ANOVA and the Mann-Whitney post-hoc test.

other hand, L. gracilis and Atherinella guatemalensis were species whose size does not differ between habitats (Fig. 4).

\section{Relationship between fish assemblages and environmental parameters}

The DistLM analysis identified four environmental variables strongly correlated with the fish assemblages when tested in isolation (marginal tests; Table 5). However, in the best solution of the full model (sequential tests, adjusted $R^{2}=0.48$ ), only habitat structure, salinity and depth together were enough to explain significantly $43 \%$ of the total variance. Selected variables by the step-wise procedure were displayed as vectors in the dbRDA ordination plot (Fig. 5). Fish assemblages modeled by four predictor variables revealed two gradients. The first gradient was related to habitat structure and salinity, which kept inlet sites separated from lagoon and channel sites. The second gradient was mainly driven by dissolved oxygen and 
Table 2. Relative importance value of the fish species for the La Joya-Buenavista lagoon-estuarine system (Mexico). Relative values based on the total number of specimens $(2,064)$, total biomass $(17,027.83 \mathrm{~g})$ and the number of sampled sites (13). n: numerical abundance; SL: size ranges in standard length; \%n: relative abundance; \%B: relative biomass; \%F: relative frequency; \%IV: relative importance value.

\begin{tabular}{|c|c|c|c|c|c|c|c|}
\hline Family & Specie & $\mathrm{n}$ & $\mathrm{SL}(\mathrm{cm})$ & $\% \mathrm{n}$ & $\% \mathrm{~B}$ & $\% \mathrm{~F}$ & $\%$ IV \\
\hline Clupeidae & Lile gracilis Castro-Aguirre \& Vivero, 1990 & 287 & $3.3-8.2$ & 13.91 & 5.52 & 6.42 & 8.61 \\
\hline Cichlidae & Astatheros macracanthus (Günther, 1864) & 208 & $2.1-13.4$ & 10.08 & 9.44 & 5.88 & 8.47 \\
\hline Mugilidae & Mugil curema Valenciennes, 1863 & 129 & 4.3-21.7 & 6.25 & 12.41 & 4.28 & 7.65 \\
\hline Gerreidae & Eucinostomus currani Zahuranec, 1980 & 206 & $1.5-9.5$ & 9.98 & 8.13 & 4.81 & 7.64 \\
\hline Eleotridae & Dormitator latifrons (Richardson, 1844) & 115 & $1.7-15.7$ & 5.57 & 14.34 & 2.67 & 7.53 \\
\hline Gerreidae & Gerres simillimus Regan, 1907 & 82 & $1.9-18.3$ & 3.97 & 10.03 & 5.35 & 6.45 \\
\hline Gerreidae & Diapterus brevirostris (Sauvage, 1879) & 113 & $2.3-8.8$ & 5.47 & 5.90 & 6.42 & 5.93 \\
\hline Poeciliidae & Poecilia nelsoni (Meek, 1904) & 200 & $1.7-5.1$ & 9.69 & 2.30 & 3.21 & 5.07 \\
\hline Centropomidae & Centropomus robalito Jordan \& Gilbert, 1882 & 121 & $3.1-16.7$ & 5.86 & 3.48 & 4.28 & 4.54 \\
\hline Cichlidae & Amphilophus trimaculatus (Günther, 1867) & 81 & $2.3-12.7$ & 3.92 & 1.54 & 3.21 & 2.89 \\
\hline Atherinopsidae & Atherinella guatemalensis (Günther, 1864) & 63 & $1.6-6.5$ & 3.05 & 0.15 & 4.28 & 2.49 \\
\hline Carangidae & Oligoplites altus (Günther, 1868) & 16 & $6.5-18.7$ & 0.78 & 2.95 & 2.67 & 2.13 \\
\hline Poeciliidae & Poecilia sphenops Valenciennes, 1846 & 75 & $2.0-5.1$ & 3.63 & 1.14 & 1.07 & 1.95 \\
\hline Engraulidae & Anchoa mundeola (Gilbert \& Pierson, 1898) & 26 & $4.0-8.4$ & 1.26 & 0.60 & 3.74 & 1.87 \\
\hline Gobiidae & Gobionellus microdon (Gilbert, 1892) & 23 & $5.3-15.0$ & 1.11 & 1.19 & 3.21 & 1.84 \\
\hline Eleotridae & Gobiomorus maculatus (Günther, 1859) & 29 & $7.5-14.1$ & 1.41 & 2.58 & 1.07 & 1.68 \\
\hline Clupeidae & Opisthonema libertate (Günther, 1867) & 47 & $5.2-7.9$ & 2.28 & 1.18 & 1.07 & 1.51 \\
\hline Gerreidae & Eugerres axillaris (Günther,1864) & 9 & $7.3-14.1$ & 0.44 & 1.53 & 2.14 & 1.37 \\
\hline Centropomidae & Centropomus armatus Gill, 1863 & 20 & $6.3-14.4$ & 0.97 & 1.49 & 1.60 & 1.36 \\
\hline Atherinopsidae & Membras gilberti (Jordan \& Bollman, 1890) & 27 & $8.3-11.1$ & 1.31 & 1.49 & 1.07 & 1.29 \\
\hline Gerreidae & Eugerres lineatus (Humboldt, 1821) & 9 & $6.3-7.5$ & 0.44 & 0.64 & 2.67 & 1.25 \\
\hline Carangidae & Caranx caninus Günther, 1867 & 10 & $4.0-13.4$ & 0.48 & 1.01 & 2.14 & 1.21 \\
\hline Centropomidae & Centropomus nigrescens Günther, 1864 & 15 & $4.7-9.6$ & 0.73 & 0.64 & 2.14 & 1.17 \\
\hline Lutjanidae & Lutjanus argentiventris (Peters, 1869) & 14 & $5.1-10.3$ & 0.68 & 1.09 & 1.60 & 1.12 \\
\hline Engraulidae & Anchoa lucida (Jordan \& Gilbert, 1882) & 15 & $5.3-8.7$ & 0.73 & 0.39 & 2.14 & 1.08 \\
\hline Lutjanidae & Lutjanus novemfasciatus Gill, 1862 & 10 & $4.2-9.4$ & 0.48 & 0.51 & 2.14 & 1.04 \\
\hline Mugilidae & Mugil cephalus Linnaeus, 1758 & 2 & $13.0-23.4$ & 0.10 & 1.45 & 1.07 & 0.87 \\
\hline Ariidae & Ariopsis guatemalensis (Günther, 1864) & 15 & $3.4-8.1$ & 0.73 & 0.21 & 1.60 & 0.85 \\
\hline Hemiramphidae & Hyporhamphus naos Banford \& Collette, 2001 & 5 & $17.4-22.5$ & 0.24 & 1.19 & 1.07 & 0.83 \\
\hline Poeciliidae & Poeciliopsis fasciata (Meek, 1904) & 14 & $1.6-2.2$ & 0.68 & 0.02 & 1.60 & 0.77 \\
\hline Engraulidae & Anchovia macrolepidota (Kner, 1863) & 15 & $6.5-14.3$ & 0.73 & 1.01 & 0.53 & 0.76 \\
\hline Paralichthyidae & Citharichthys gilberti Jenkins \& Evermann, 1889 & 7 & $5.8-14.1$ & 0.34 & 0.72 & 1.07 & 0.71 \\
\hline Clupleidae & Lile nigrofasciata Castro-Aguirre, Ruiz-Campos \& Balart, 2002 & 12 & $6.2-7.4$ & 0.58 & 0.32 & 1.07 & 0.66 \\
\hline Carangidae & Oligoplites saurus (Bloch \& Schneider, 1801) & 4 & 10.3-14.5 & 0.19 & 0.62 & 1.07 & 0.63 \\
\hline Ariidae & Cathorops liropus (Bristol, 1897) & 3 & $12.2-13.7$ & 0.15 & 0.63 & 1.07 & 0.61 \\
\hline Lutjanidae & Lutjanus colorado Jordan \& Gilbert, 1882 & 2 & $8.9-15.8$ & 0.10 & 0.60 & 1.07 & 0.59 \\
\hline Centropomidae & Centropomus viridis Lockington, 1877 & 5 & $5.6-11.0$ & 0.24 & 0.31 & 1.07 & 0.54 \\
\hline Tetraodontidae & Sphoeroides annulatus (Jenyns, 1842) & 3 & $4.5-5.2$ & 0.15 & 0.14 & 1.07 & 0.45 \\
\hline Ariidae & Cathorops steindachneri (Gilbert \& Starks, 1904) & 4 & $4.7-5.5$ & 0.19 & 0.06 & 1.07 & 0.44 \\
\hline Achiridae & Achirus mazatlanus (Steindachner, 1869) & 3 & $3.1-3.8$ & 0.15 & 0.02 & 1.07 & 0.41 \\
\hline Poeciliidae & Poeciliopsis pleurospilus (Günther, 1866) & 9 & $1.8-3.2$ & 0.44 & 0.05 & 0.53 & 0.34 \\
\hline Anablepidae & Anableps dowei Gill, 1861 & 3 & $6.6-11.5$ & 0.15 & 0.26 & 0.53 & 0.31 \\
\hline Mugilidae & Mugil hospes Jordan \& Culver, 1865 & 2 & $8.3-10.2$ & 0.10 & 0.23 & 0.53 & 0.29 \\
\hline Haemulidae & Haemulopsis axillaris (Steindachner, 1869) & 1 & 10.8 & 0.05 & 0.21 & 0.53 & 0.26 \\
\hline Haemulidae & Orthopristis chalceus (Günther, 1864) & 1 & 10.1 & 0.05 & 0.19 & 0.53 & 0.26 \\
\hline Labridae & Halichoeres dispilus (Günther, 1864) & 1 & 8.4 & 0.05 & 0.07 & 0.53 & 0.22 \\
\hline Gobiidae & Aboma etheostoma Jordan \& Starks, 1895 & 2 & $1.7-1.8$ & 0.10 & 0.00 & 0.53 & 0.21 \\
\hline Characidae & Astyanax aeneus (Günther, 1860) & 1 & 4.6 & 0.05 & 0.02 & 0.53 & 0.20 \\
\hline
\end{tabular}


Table 3. Results of PERMANOVA based on Bray-Curtis dissimilarities on fish abundance data in response to season, habitat, months, sampling sites, and their interactions in the La Joya-Buenavista lagoon-estuarine (LJB) system (Mexico). d.f.: degrees of freedom, MS: mean square; $F$ : pseudo- $F$ statistic value, $P: P$-values by permutation. Permutated residuals under a reduced model (Type III). The maximum number of permutations $=9,999$. Significant $P$-values $(<0.05)$ are in bold.

\begin{tabular}{lccrl}
\hline Source of variation & d.f. & MS & $F$ & $P$ \\
\hline Habitat $(\mathrm{Ha})$ & 2 & 25960 & 11.24 & $\mathbf{0 . 0 0 0 1}$ \\
Season $(\mathrm{Se})$ & 3 & 5438.5 & 2.35 & $\mathbf{0 . 0 0 2}$ \\
Sampling site $(\mathrm{Si}$, nested in Ha) & 10 & 3748.1 & 1.62 & $\mathbf{0 . 0 0 8}$ \\
Month $(\mathrm{Mo}$, nested in Se) & 2 & 2397 & 1.04 & 0.426 \\
$\mathrm{Ha} \times \mathrm{Se}$ & 6 & 5098.3 & 2.21 & $\mathbf{0 . 0 0 0 4}$ \\
$\mathrm{Ha} \times \mathrm{Mo}$ & 4 & 2314.3 & 1.00 & 0.474 \\
$\mathrm{Se} \times \mathrm{Si}$ & 30 & 2459.6 & 1.06 & 0.348 \\
Residuals & 20 & 2310 & & \\
\hline
\end{tabular}

Table 4. Discrimination of 10 fish species based on its relative contribution among habitats by SIMPER analysis; La JoyaBuenavista lagoon-estuarine (LJB) system (Mexico). Ecological category: E: estuarine resident, EU: marine euryhaline, ST: marine stenohaline, SF: secondary freshwater. Functional group: DV: detritivore, OV: omnivore, PV: piscivore, ZB: zoobenthivore, ZP: zooplanktivore, I: inlet, C: channel, L: lagoon.

\begin{tabular}{|c|c|c|c|c|c|c|c|}
\hline \multirow{2}{*}{ Species } & \multirow{2}{*}{$\begin{array}{c}\text { Ecological } \\
\text { category }\end{array}$} & \multirow{2}{*}{$\begin{array}{l}\text { Functional } \\
\text { group }\end{array}$} & \multicolumn{2}{|c|}{ Spatial distribution } & \multicolumn{3}{|c|}{ Contribution (\%) } \\
\hline & & & I $\quad$ C & $\mathrm{L}$ & $\mathrm{L} v s \mathrm{I}$ & $\mathrm{L} v s \mathrm{C}$ & $\mathrm{I} v s \mathrm{C}$ \\
\hline Eucinostomus currani & EU & $\mathrm{OV}$ & & & 14.66 & 3.52 & 16.01 \\
\hline Centropomus robalito & EU & PV & & & 2.35 & 12.79 & 10.02 \\
\hline Diapterus brevirostris & EU & $\mathrm{OV}$ & & & 7.09 & 6.72 & 5.68 \\
\hline Lile gracilis & $\mathrm{E}$ & $\mathrm{ZP}$ & & & 5.72 & 8.62 & 2.49 \\
\hline Astatheros macracanthus & $\mathrm{SF}$ & $\mathrm{OV}$ & & & 4.88 & 7.62 & 4.43 \\
\hline Dormitator latifrons & $\mathrm{E}$ & DV & & & - & 8.86 & 6.47 \\
\hline Atherinella guatemalensis & $\mathrm{E}$ & ZB & & & 7.55 & - & 6.90 \\
\hline Lutjanus argentiventris & ST & PV & & & 5.17 & - & 4.78 \\
\hline Gerres simillimus & EU & OV & & & 4.65 & 5.86 & - \\
\hline Mugil curema & EU & DV & & & 4.58 & 2.93 & 2.99 \\
\hline
\end{tabular}

depth, discriminating against the lagoon sites from the channel sites.

\section{DISCUSSION}

The specific richness in the LJB system (48 species) was higher than that described in other ecological studies carried out in the Gulf of Tehuantepec. In the southern Gulf, richness varied between 31 species in the Chantuto-Panzacola system (Díaz-Ruiz et al., 2004) and 40 in Carretas-Pereyra (Velázquez-Velázquez et al., 2008). However, in the first case, comparisons between the fish assemblages should be taken with caution, due to the difference in the sampling effort and method. In the second case, the sampling was more comparable with this study, and differences in richness and composition may be due to less marine influence due to mouth dynamics (Gómez-González et al., 2012). Although it has been pointed out that the use of a single fishing gear results in a biased sample of the assemblage (Clement et al., 2014), in estuarine wetlands the use of cast nets is highly effective for achieving a broad taxonomic representation in several shallow habitats, and with accurate estimate of abundances (Sheaves et al., 2007; Sheaves \& Johnston, 2009). However, highly complex habitats should be explored to avoid underrepresenting the cryptic fish fauna.

According to our hypothesis, we found that the fish fauna varied significantly within each geomorphic habitat. When abundances of 48 species at 72 sampling events are ordered on the two primary axes of dbRDA (Fig. 5), a spatial pattern response in fish assemblages on the lagoon, inlet and the channel is identified (Table 4; Fig. 3, 5). The lagoon exhibits a greater richness (35 spp.) with smaller sizes, compared to the inlet (20 spp.) and the channel (17 spp.), suggesting differentiated use of the habitat or the existence of assemblages with their ecological attributes. The above could also be reflected in the percentages of the functional guilds in each habitat (e.g., a greater number of omnivores in the lagoon; Table 4). 


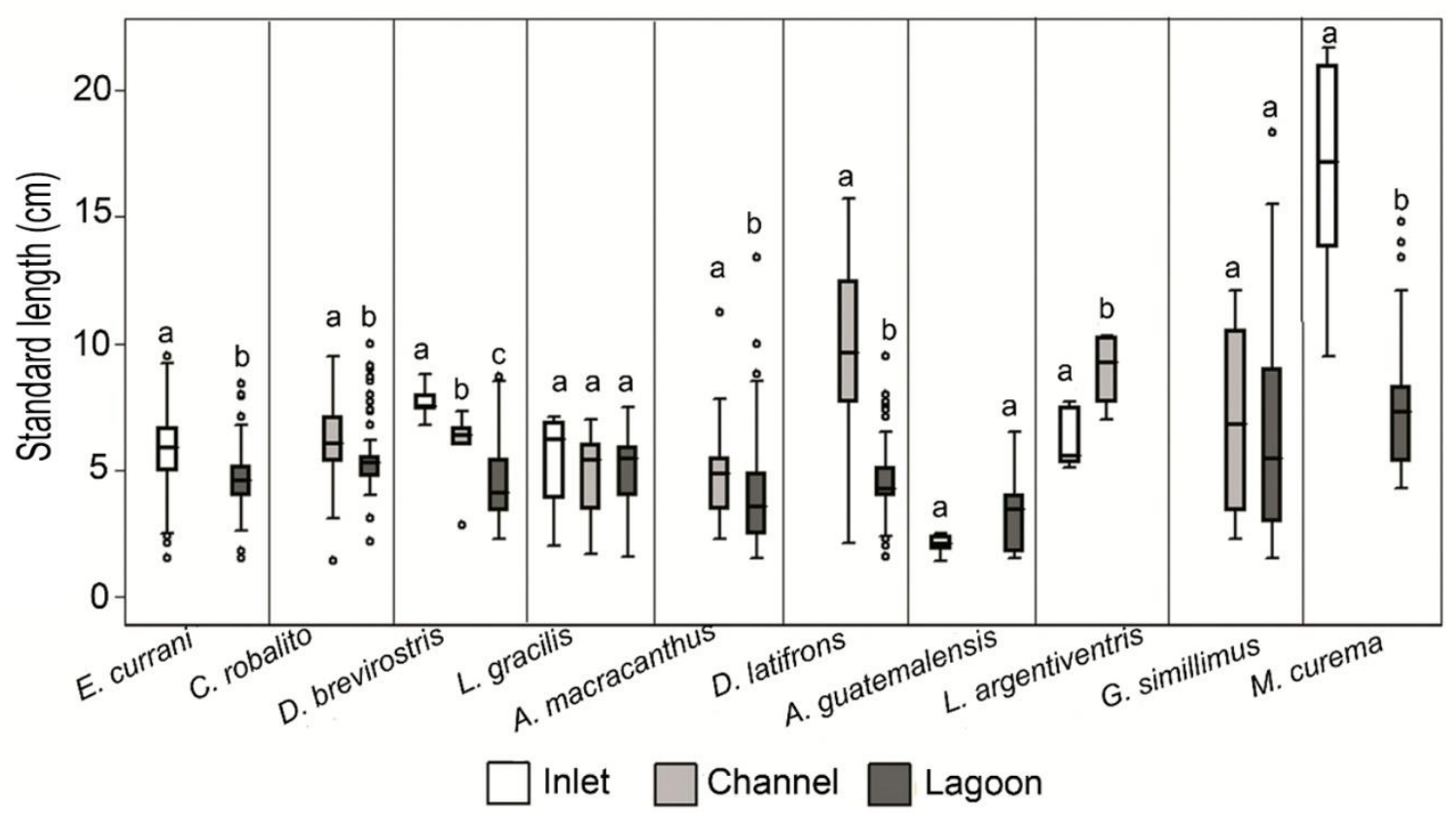

Figure 4. Standard length distribution of 10 species identified by SIMPER. Within species, the distributions sharing the same letter were not significantly different on $P<0.05$ with the non-parametric ANOVA and the Mann-Whitney pairwise test.

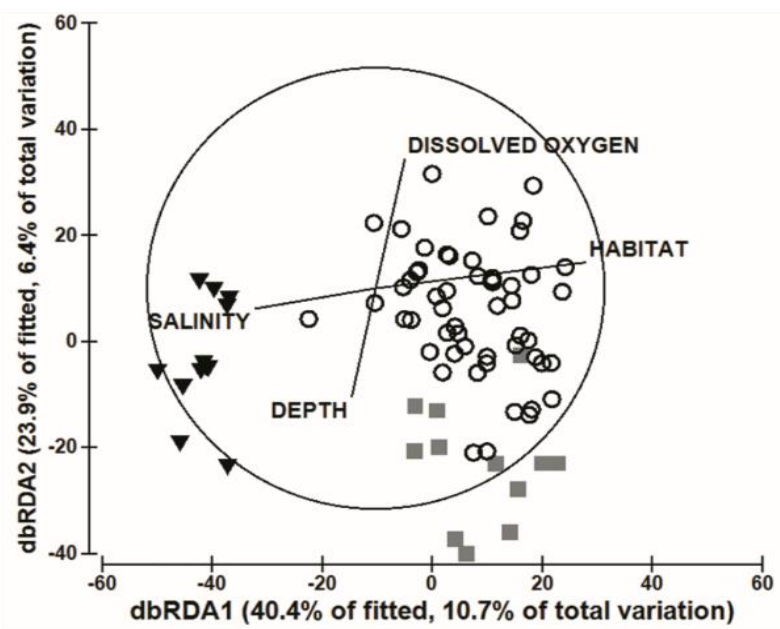

Figure 5. Distance-based redundancy analysis biplot based on linear modelling for fish abundance data, La Joya-Buenavista lagoon-estuarine system, Mexico. Vectors indicate correlations between the four environmental parameters of most significance in the model and the axes. The length and direction of the vectors represent the strength of the relationship concerning a unit circle. Symbols represent an individual sampling event coded by habitat. Black triangles: inlet, gray squares: channel, white circles: lagoon.

In the LJB system, the connectivity among the three geomorphic habitats may be a key attribute that defines the small-scale variation of fish assemblages. Similar
Table 5. Marginal and sequential tests result for the distance-based linear models based on fish abundance data in the La Joya-Buenavista lagoon-estuarine (LJB) system (Mexico). SS: sum of squares; $F$ : pseudo- $F$ statistic value; $P: P$-value of permutation test for the relationship between the fish assemblages and environmental parameters. Significant $P$-values $(<0.05)$ are in bold.

\begin{tabular}{lccc}
\hline Variable & SS trace & $F$ & $P$ \\
\hline Marginal test & & & \\
Habitat structure & 11536 & 4.25 & $\mathbf{0 . 0 0 1}$ \\
Depth & 6417 & 2.17 & $\mathbf{0 . 0 3 6}$ \\
Dissolved oxygen & 6163 & 2.02 & $\mathbf{0 . 0 4 2}$ \\
Salinity & 6088 & 1.99 & $\mathbf{0 . 0 4 6}$ \\
Water clarity & 4375 & 1.38 & 0.209 \\
pH & 3694 & 1.15 & 0.300 \\
Water temperature & 1799 & 0.54 & 0.847 \\
\hline Sequential test & & & \\
Habitat structure & 11536 & 4.25 & $\mathbf{0 . 0 0 1}$ \\
Depth & 6713 & 2.74 & $\mathbf{0 . 0 0 9}$ \\
Salinity & 4091 & 1.76 & $\mathbf{0 . 0 5 0}$ \\
\hline
\end{tabular}

spatial patterns were described by França et al. (2009) and Neves et al. (2013) in temperate and tropical coastal lagoons. If the habitats offer differentiated resources in food and shelter, the sequential use of these will favor an efficient use of the lagoon-estuarine system as a whole (Abrantes et al., 2015; Loureiro et $a l ., 2016)$. Also, the results obtained here are consistent 
with the theory that the seascape/landscape structure plays a determinant role in the structure of fish assemblages (Kimirei et al., 2013).

Although differences were found at the temporal level, the spatial variations among geomorphic habitats were more significant (Table 3), probably due to a higher number of dominant species residing into the system during the entire annual cycle, and whose movements depend on the availability of resources (Lukey et al., 2006; Herzka et al., 2009). Another explanatory factor could be the relative environmental stability of the system. The significant spatio-temporal interactions detected, habitat $\times$ season and between sampling sites, can be indicative of seasonal pulses that define variations in physical and chemical properties within the same ecological or spatial unit (YáñezArancibia et al., 1983; Roselli et al., 2013). However, the lowest relationship found at a temporal scale could be because only one annual cycle was evaluated. Therefore, a study in time series would be required to corroborate these results.

The presence of large areas of complex habitats, like mangroves, is a key factor why fish use lagoon estuarine systems as nurseries. Mangroves support more diverse and abundant small-sized fish assemblages, as they favor greater protection from predators and increase food availability (Nagelkerken et al., 2002; Hindell \& Jenkins, 2004; Piko \& Szedlmayer, 2007; Green et al., 2012; Neves et al., 2013). The sheltered lagoon and the riverine mangroves that border the channel are suitable habitats for the fish fauna in the LJB system. However, during the dry season, the mangrove root system is not available for fishes; thus, the lack of physical structure may result in a reduction of shelter. Therefore, the highest abundance and richness of species in the lagoon, compared with the other habitats, suggests that this area has a significant ecological value. In this order, Franco et al. (2006) and Verdiell-Cubedo et al. (2013) have reported high abundance values in shallow habitats with small patches of macrophytes or perimetral lagoon marshlands, suggesting that juvenile fish use openlagoon areas for feeding (Arceo-Carranza \& ChiappaCarrara, 2013; Kathoon et al., 2014). The high abundance of species with detritivore, zoobenthivore and zooplanktivore feeding habits (e.g., Mugil curema, Lile gracilis, Atherinella guatemalensis) were recorded in the lagoon area (Table 4), suggesting that both the physical and biotic attributes of this habitat influenced the population traits of these species.

The proximity of mangroves and mixed substrates also contributes to increasing the complexity of the channel; however, this habitat presented less abundance and richness concerning the inlet, considered of low complexity (Lacerda et al., 2014). However, it has been reported that in tropical estuaries, there are lower values of abundance and richness associated with the mouth area (Neves et al., 2013). Even though, in our study, the inlet is the richest species area of all estuarine channel, which may be due to the occurrence of rare species, mainly of stenohaline affinity (Peralta-Meixueiro \& Vega-Cendejas, 2011), during the pre-dry and dry seasons. During the rainy season, freshwater inputs modify the hydrology (salinity, dissolved oxygen, temperature), with a higher number of estuarine species attracted to the beach by a high density of such prey (e.g., Litopenaeus spp.). On the other hand, during the dry season, the beach environment becomes similar to the marine zone, with a lower abundance of fish but a higher richness and dominance of some families (e.g., Carangidae and Sciaenidae).

A meaningful relationship has been founded for several environments between the habitat complexity and the structure of animal assemblages. The ecological paradigm holds that the most complex and physically heterogeneous habitats will support more diverse communities (Stewart et al., 2000). An increase in available refuges due to microtopographic variations of the substrate or physical structures also has been shown to reduce inter and intra-specific competition for space, which potentially increases the richness and abundance of fish (Almany, 2004; Consoli et al., 2018).

Some of the dominant species found in the lagoon and the channel are secondary freshwater and estuarine residents (e.g., Dormitator latifrons and Astatheros macracanthus). The distribution and population structure of this group are determined by a temporal pattern affecting hydrological conditions (Díaz-Ruiz et al., 2004; Velázquez-Velázquez et al., 2008). During the rains, larger organisms were found in the channel, while juveniles of these species occurred in the lagoon during the pre-dry and dry seasons, suggesting a local migration from the streams to mesohaline environments.

In the LJB system, families such as Gerreidae and Mugilidae present greater abundances of larger organisms in the inlet than in the lagoon, suggesting that the sandy bars play an important and specific role for providing habitat. For example, in northern Australia, Blaber et al. (1995) found that the tidal environment, located between the mouth of an open estuary and the adjacent lower marine zone, sustains a relatively complex fish assemblage, composed by dependent juveniles as well as groups of opportunistic species that are move through three habitats (estuary, inshore and offshore waters). The structure of a similar assemblage occurs in the inlet of the LJB system, where juveniles of some species (e.g., Lutjanus argentiventris) 
were found exclusively in this area, and others of distribution extended by all habitats without variations in their size (e.g., L. gracilis).

Water depth could be a parameter strongly correlated to abundance and size structure in the biotic assemblages of an estuarine system. A general pattern observed shows that larger fishes will be more abundant in deeper habitats, whereas smaller ones will be more abundant in shallow environments (Hutchinson et al., 2014; Mustamäki et al., 2015; Becker et al., 2017). In the LJB system, the greatest depths were recorded in the channel, which may explain the occurrence of larger specimens from families as Lutjanidae, Centropomidae and Cichlidae (Fig. 4); this habitat could be used as a transit or feeding zone in mangroves and marginal lowlands. Hypoxia and low-depth are significant barriers to the presence of larger predatory fish in the lagoon. They affect their ability to move and evade predation, due to physiological stress (Patterson \& Whitfield, 2000; Shoji et al., 2005), so greater impact towards recruits will be inflicted by small and juvenile piscivores (Baker \& Sheaves, 2009); further evidence for a specific trophic structure for each habitat in the environment (Tecchio et al., 2015).

Although there were seasonal differences, the evidence of fish-habitat associations for many species was broad regardless of seasonality, probably because a high percentage of resident species in the system was found during the annual cycle. However, sampling needs to be expanded to compare contiguous systems and between-year variations in order to corroborate these conclusions. Several anthropogenic pressures are affecting the lagoon estuaries of the Gulf of Tehuantepec, whose vulnerability has increased in recent years as a result of the lack of planning in the coastal basin. Due to their ability to respond to environmental changes, fish assemblages are a potential tool for monitoring the ecological integrity of coastal systems, so their study should be continued. Likewise, coastal management should be developed to conserve the mosaic of habitats that integrate all the system, rather than distinct habitats.

\section{ACKNOWLEDGMENTS}

We thank the Cooperative Society of Fish Production "Miguel Hidalgo y Costilla" for their participation in the collection data. The authors would also like to thank Manuel Anzueto and Eduardo Urbina for their field and lab technical assistance. Comments on a manuscript from Wilfredo Matamoros helped to improve the final version substantially. This paper is part of the first author's Doctor of Science dissertation at the Univer- sidad Nacional Autónoma de México (UNAM). The Mexican Consejo Nacional de Ciencia y Tecnología (CONACYT) granted a scholarship to the first author.

\section{REFERENCES}

Abrantes, K.G., Barnett, A., Baker, R. \& Sheaves, M. 2015. Habitat-specific food webs and trophic interactions supporting coastal-dependent fishery species: an Australian case study. Reviews in Fish Biology and Fisheries, 25(2): 337-363. doi: 10.1007/ s11160-015-9385-y

Almany, G.R. 2004. Does increased habitat complexity reduce predation and competition in coral reef fish assemblages? Oikos, 106: 275-284.

Anderson, M.J. 2001. A new method for non-parametric multivariate analysis of variance. Australian Journal of Ecology, 26: 32-46. doi: 10.1111/j.1442-9993.2001. 01070.pp.x

Anderson, M.J. 2006. Distance-based tests for homogeneity of multivariate dispersions. Biometrics, 62: 245-253.

Anderson, M.J., Gorley, R.N. \& Clarke, K.R. 2008. PERMANOVA+ for PRIMER: guide to software and statistical methods. PRIMER-E, Plymouth.

Arceo-Carranza, D. \& Chiappa-Carrara, X. 2013. Feeding ecology of juvenile marine fish in a shallow coastal lagoon of south-eastern Mexico. Latin American Journal of Aquatic Research, 43(4): 621-631. doi: 10.3856/vol43-issue4-fulltext-1

Ayala-Pérez, L.A., Vasco-Villa, O. \& Sosa-López, A. 2014. Evaluación de las asociaciones de peces dominantes influenciadas por el ciclo nictemeral y la variación temporal en la Reserva de la Biósfera Los Petenes, Campeche, México. Ciencia UAT, 9(1): 3343.

Baker, R. \& Sheaves, M. 2009. Overlooked small and juvenile piscivores dominate shallow-water estuarine "refuges" in tropical Australia. Estuarine, Coastal and Shelf Science, 85(4): 618-626. doi: 10.1016/j.ecss. 2009.10.006

Bakun, A., Csirke, J., Lluch-Belda, S. \& Steer-Ruiz, R. 1999. The Pacific Central American Coastal LME. In: Sherman, K. \& Tang, Q. (Eds.). Large marine ecosystems of the Pacific Rim. Blackwell Science, Cambridge, pp. 268-280.

Bartholomew, A., Diaz, R.J. \& Cicchetti, G. 2000. New dimensionless indices of structural habitat complexity: predicted and real effects on a predator's foraging success. Marine Ecology Progress Series, 206: 45-58. doi: 10.3354/meps206045

Becker, A., Whitfield, A.K., Cowley, P.D. \& Cole, V.J. 2017. Does water depth influence the size composition of estuary-associated fish? Distributions revealed 
using mobile acoustic-camera transect along the channel of a small shallow estuary. Marine and Freshwater Research, 68: 2163-2169. doi: 10.1071/ MF16230

Blaber, S.J.M., Brewer, D.T. \& Salini, J.P. 1995. Fish communities and the nursery role of the shallow inshore waters of a tropical bay in the Gulf of Carpenteria, Australia. Estuarine, Coastal and Shelf Science, 40: 177-193. doi: 10.1016/S0272-7714(05) 80004-6

Castillo-Rivera, M., Zárate-Hernández, R., Ortiz-Burgos, S. \& Zavala-Hurtado, J. 2010. Diel and seasonal variability in the fish community structure of a mudbottom estuarine habitat in the Gulf of Mexico. Marine Ecology, 31: 633-642. doi: 10.1111/j.1439-0485.2010. 00394.x

Castro-Aguirre, J.L., Espinosa-Pérez, H.S. \& SchmitterSoto, J.J. 1999. Ictiofauna estuarino-lagunar y vicaria de México. Limusa-Noriega, Ciudad de México.

Clarke, K.R. 1993. Non-parametric multivariate analyses of changes in community structure. Australian Journal of Ecology, 18: 117-143. doi: 10.1111/j.1442-9993. 1993.tb00438.x

Clarke, K.R. \& Gorley, R.N. 2006. PRIMER 6: user manual-tutorial. PRIMER-E, Plymouth.

Clement, T.A., Pangle, K., Uzarski, D.G. \& Murray, D.A. 2014. Effectiveness of fishing gears to assess fish assemblage size structure in small lake ecosystems. Fisheries Management and Ecology, 21: 211-219. doi: 10.1111/fme.12069

Colwell, R.K., Chao, A., Gotelli, N.J., Lin, S., Mao, C.X., Chazdon, R.L. \& Longino, J.T. 2012. Models and estimators linking individual-based and sample-based rarefaction, extrapolation, and comparison of assemblages. Journal of Plant Ecology, 5(1): 3-21. doi: 10.1093/jpe/rtr044

Consoli, P., Mangano, M.C., Sarà, G., Romeo, T. \& Andaloro, F. 2018. The influence of habitat complexity on fish assemblages associated with extractive platforms in the central Mediterranean Sea. Advances in Oceanography and Limnology, 9(2): 59-67. doi: 10.4081/aiol.2018.7918

Contreras, E.F. 2010. Ecosistemas costeros mexicanos: una actualización. Universidad Autónoma Metropolitana, Unidad Iztapalapa, Ciudad de México.

Contreras, E.F. \& Zabalegui, M.LM. 1991. Hidrología, nutrientes y productividad primaria en la laguna La Joya-Buenavista, Chiapas, México. Anales del Instituto de Ciencias del Mar y Limnología, 18(2): 207-215.
Day Jr., J.W., Hall, C.A.S., Kemp, W.M., YáñezArancibia, A. \& Crump, B.C. (Eds.). 2012. Estuarine ecology. Wiley-Blackwell, New York.

Díaz-Ruiz, S., Cano-Quiroga, E., Aguirre-León, A. \& Ortega-Bernal, R. 2004. Diversidad, abundancia y conjuntos ictiofaunisticos del sistema lagunarestuarino Chantuto-Panzacola, Chiapas, México. Revista de Biología Tropical, 52(1): 187-199. doi: 10.15517/ RBT.V52I1.14879

Elliott, M., Whitfield, A.K., Potter, I.C., Blaber, S.J.M., Cyrus, D.P., Nordlie, F.G. \& Harrison, T.D. 2007. The guild approach to categorizing estuarine fish assemblages: a global review. Fish and Fisheries, 8: 241-268. doi: 10.1111/j.1467-2679.2007.00253.x

França, S., Costa, M.J. \& Cabral, H.N. 2009. Assessing habitat-specific fish assemblages in estuaries along the Portuguese coast. Estuarine, Coastal and Shelf Science, 83: 1-12. doi: 10.1016/j.ecss.2009.03.013

França, S., Vasconcelos, R.P., Fonseca, V.F., Tanner, S.E., Reis-Santos, P., Costa, M.J. \& Cabral, H.N. 2012. Predicting fish community properties within estuaries: influence of habitat type and other environmental features. Estuarine, Coastal and Shelf Science, 107: 22-31. doi: 10.1016/j.ecss.2012.04.013

Franco, A., Torricelli, P. \& Franzoi, P. 2009. A habitatspecific fish-based approach to assess the ecological status of Mediterranean coastal lagoons. Marine Pollution Bulletin, 58: 1704-1717. doi: 10.1016/ j.marpolbul.2009.06.016

Franco, A., Franzoi, P., Malavasi, S., Riccato, F., Torricelli, P. \& Mainardi, D. 2006. Use of shallow water habitats by fish assemblages in a Mediterranean coastal lagoon. Estuarine, Coastal and Shelf Science, 66: 67-83. doi: 10.1016/j.ecss.2005.07.020

Fricke, R., Eschmeyer, W.N. \& Van der Laan, R. (Eds.). 2019. Eschmeyer's catalog of fishes: genera, species, references. California Academy of Sciences, California. [http://researcharchive.calacademy.org/ research/ichthyology/catalog/fishcatmain.asp]. Reviewed: Jun 28, 2019.

Froese, R. \& Pauly, D. 2016. FishBase. [www. fishbase.org]. Reviewed: October 16, 2016.

Gómez-González, A.E., Velázquez-Velázquez, E., RodilesHernández, R., González-Díaz, A.A., González-Acosta, A.F. \& Castro-Aguirre, J.L. 2012. Lista sistemática de la ictiofauna en la Reserva de la Biosfera La Encrucijada, Chiapas, México. Revista Mexicana de Biodiversidad, 83: 674-686. doi: 10.7550/rmb.24468

González-Acosta, A.F., Rodiles-Hernández, R. \& González-Díaz, A.A. 2017. Checklist of the marine and estuarine fishes of Chiapas, Mexico. Marine Biodiversity, 48: 1439-1454. doi: 10.1007/s12526016-0630-y 
Green, B.C., Smith, D.J. \& Underwood, G.J.C. 2012. Habitat connectivity and spatial complexity differentially affected mangrove and salt marsh fish assemblages. Marine Ecology Progress. Series, 466: 177-192. doi: 10.3354/meps09791

Griffiths, S.P. 2001. Factors influencing fish composition in an Australian intermittently open estuary. Is stability salinity-dependent? Estuarine, Coastal and Shelf Science, 52: 739-751. doi: 10.1006/ecss.2000. 0756

Herzka, S.Z., Griffiths, R., Fodrie, F.J. \& McCarthy, I.D. 2009. Short-term size-specific distribution and movement patterns of juvenile flatfish in a Pacific estuary derived through length-frequency and markrecapture data. Ciencias Marinas, 35: 41-57.

Hicks, A., Barbee, N.C., Swearer, S.E. \& Downes, B.J. 2010. Estuarine geomorphology and low salinity requirement for fertilization influence spawning site location in the diadromous fish, Galaxias maculatus. Marine and Freshwater Research, 61(11): 1252-1258. doi: 10.1071/MF10011

Hindell, J.S. \& Jenkins, G.P. 2004. Spatial and temporal variability in the assemblage structure of fishes associated with mangroves (Avicennia marina) and intertidal mudflats in temperate Australian embayments. Marine Biology, 144: 385-395. doi: 10.1007/s00227-003-1201-x

Hutchinson, N., Jenkins, G.P., Smith, T.M. \& Brown, A. 2014. Variation with depth in temperate seagrassassociated fish assemblages in southern Victoria, Australia. Estuaries and Coasts, 37: 801-814. doi: 10.1007/s12237-013-9742-9

Kathoon, Z., Paperno, R. \& Makhdoom-Hussain, S. 2014. Spatial and temporal changes in the fish communities from a mangrove-dominated creek system near Karachi, Pakistan. Journal of Applied Ichthyology, 30: 350-358. doi: 10.1111/jai.12377

Kimirei, I.A., Nagelkerken, I., Mgaya, Y.D. \& Huijbers, C.M. 2013. The mangrove nursery paradigm revisited: otolith stable isotopes support nursery-to-reef movements to Indo-Pacific fishes. Plos One, 8(6): e66320. doi: 10.1371/journal.pone.0066320

Krebs, C.J. 1999. Ecological methodology. AddisonWesley, California.

Lacerda, C.H.F., Barletta, M. \& Dantas, D.V. 2014. Temporal patterns in the intertidal faunal community at the mouth of a tropical estuary. Journal of Fish Biology, 85: 1571-1602. doi: 10.1111/jfb. 12518

Lankford, R.R. 1977. Coastal lagoons of Mexico. Their origin and classification. In: Wiley, M. (Ed.). Estuarine processes. Circulation, sediments, and transfer of material in the estuary. Academic Press, New York, pp. 182-215.

Legendre, P. \& Anderson, M.J. 1999. Distance-based redundancy analysis: testing multispecies responses to multifactorial ecological experiments. Ecological Monographs, 69: 1-24. doi: 10.2307/2657192

Loureiro, S.N., Reis-Filho, J.A. \& Giarrizzo, T. 2016. Evidence for habitat-driven segregation of an estuarine fish assemblage. Journal of Fish Biology, 89: 804-820. doi: $10.1111 / \mathrm{jfb} .13017$

Lukey, J.R., Booth, A.J. \& Froneman, P.W. 2006. Fish population size and movement patterns in a small intermittently open South African estuary. Estuarine, Coastal and Shelf Science, 67: 10-20. doi: 10.1016/j.ecss.2005.10.021

McArdle, B.H. \& Anderson, M.J. 2001. Fitting multivariate models to community data: a comment on distance-based redundancy analysis. Ecology, 82: 290297. doi: $10.2307 / 2680104$

McLusky, D.S. \& Elliott, M. 2004. The estuarine ecosystem: ecology, threats and management. University Press, Oxford.

Mendoza, E., Castillo-Rivera, M., Zárate-Hernández, R. \& Ortiz-Burgos, S. 2009. Seasonal variations in the diversity, abundance, and composition of species in an estuarine fish community in the Tropical Eastern Pacific, Mexico. Ichthyological Research, 56: 330339. doi: 10.1007/s10228-009-0102-5

Mustamäki, N., Jokinen, H., Scheinin, M., Bonsdorff, E. \& Mattila, J. 2015. Seasonal small-scale variation in distribution among depth zones in a coastal Baltic Sea fish assemblage. ICES Journal of Marine Science, 72(8): 2374-2384. doi: 10.1093/icesjms/fsv068

Myers, G.S. 1966. Derivation of the freshwater fish fauna of Central America. Copeia, 1966(4): 733-766.

Nagelkerken, I. \& Van der Velde, G. 2002. Do nonestuarine mangroves harbor higher densities of juvenile fish than adjacent shallow-water and coral reef habitats in Curaçao (Netherlands Antilles)? Marine Ecology Progress Series, 245: 191-204. doi: 10.3354/meps 245191

Neves, L.M., Teixeira, T.P. \& Araújo, F.G. 2011. Structure and dynamics of distinct fish assemblages in three reaches (upper, middle and lower) of an open tropical estuary in Brazil. Marine Ecology, 32: 115131. doi: 10.1111/j.1439-0485.2010.00407.x

Neves, L.M., Teixeira, T.P., Franco, T.P., Pereira, H. \& Araújo, F.G. 2013. Fish composition and assemblage structure in the estuarine mixing zone of a tropical estuary: comparisons between the main channel and an 
adjacent lagoon. Marine Biology Research, 9(7): 661675. doi: 10.1080/17451000.2013.765575

Oksanen, J., Blanchet, F.G., Kindt, R., Legendre, P., Minchin, P.R., O`Hara, R.B., Simpson, G.L., Solymos, P., Stevens, M.H.M. \& Wagner, H. 2014. Vegan: community ecology package, version 2.2. [http:// vegan.r-force.r-project.org]. Reviewed: June 12, 2016.

Ortega-García, S., Trigueros-Salmerón, J.A., RodríguezSánchez, R., Lluch-Cota, S. \& Villalobos, H. 2000. El Golfo de Tehuantepec como un centro de actividad biológica y su importancia en las pesquerías. In: Lluch-Belda, D., Elorduy-Garay, J., Lluch-Cota, S. \& Ponce-Díaz, G. (Eds.). BAC: centros de actividad biológica en el Pacífico Mexicano. Centro de Investigaciones Biológicas del Noroeste S.C., La Paz, pp. 335-356.

Patterson, A.W. \& Whitfield, A.K. 2000. Do shallowwater habitats function as refugia for juvenile fishes? Estuarine, Coastal and Shelf Science, 51: 359-364. doi: 10.1006/ ecss.2000.0640

Peralta-Meixueiro, M.A. \& Vega-Cendejas, M.E. 2011. Spatial and temporal structure of fish assemblages in a hyperhaline coastal system: Ría Lagartos, Mexico. Neotropical Ichthyology, 9(3): 673-682. doi: 10.1590/ S1679-62252011005000033

Pérez-Ruzafa, A., Monpéan, C. \& Marcos, C. 2007. Hydrographic, geomorphologic and fish assemblage relationship in coastal lagoons. Hydrobiologia, 577(1): 107-125. doi: 10.1007/978-1-4020-6008-3_10

Piko, A.A. \& Szedlmayer, S.T. 2007. Effects of habitat complexity and predator exclusion on the abundance of juvenile red snapper. Journal of Fish Biology, 70: 758-769. doi: 10.1111/j.1095-8649.2007.01336.x

R Development Core Team. 2014. R: a language and environment for statistical computing version 3.1.2. $\mathrm{R}$ Foundation for Statistical Computing. [http://rproject.org]. Reviewed: June 12, 2016.

Rodríguez-Romero, J., López-González, L.C., GalvánMagaña, F., Sánchez-Gutiérrez, F.J., Inohuye-Rivera, R.B. \& Pérez-Urbiola, J.C. 2011. Seasonal changes in a fish assemblage associated with mangroves in a coastal lagoon of Baja California Sur, Mexico. Latin American Journal of Aquatic Research, 39(2): 250260. doi: 10.3856/vol39-issue2-fulltext-6

Roselli, L., Cañedo-Argüelles, M., Goela, P.C., Cristina, S., Rieradevall, M., D’Adamo, R. \& Newton, A. 2013. Do physiography and hydrology determine the physicochemical properties and trophic status of coastal lagoons? A comparative approach. Estuarine, Coastal and Shelf Science, 117: 29-36. doi: 10.1016/ j.ecss.2012.09.014

Saintilan, N. 2004. Relationships between estuarine geomorphology, wetland extent and fish landings in New South Wales estuaries. Estuarine, Coastal and
Shelf Science, 61: 591-601. doi: 10.1016/j.ecss.2004. 07.002

Sheaves, M. \& Johnston, R. 2009. Ecological drivers of spatial variability among fish fauna of 21 tropical Australian estuaries. Marine Ecology Progress Series, 385: 245-260. doi: 10.3354/meps08040

Sheaves, M., Johnston, R. \& Abrantes, K. 2007. Fish fauna of dry tropical and subtropical estuarine floodplain wetlands. Marine and Freshwater Research, 58: 931-943. doi: 10.1071/MF06246

Sheaves, M., Johnston, R. \& Conolly, R.M. 2012. Fish assemblages as indicators of estuary ecosystem health. Wetlands Ecology and Management, 20: 477-490. doi: 10.1007/s11273-012-9270-6

Shoji, J., Masuda, R., Yamashita, Y. \& Tanaka, M. 2005. Effect of low dissolved oxygen concentrations on behavior and predation rates on red sea bream Pagrus major larvae by the jellyfish Aurelia aurita and by juvenile Spanish mackerel Scomberomorus niphonius. Marine Biology, 147(4): 863-868. doi: 10.1007/ s00227-005-1579-8

Sindilariu, P., Freyhof, J. \& Wolter, C. 2006. Habitat use of juvenile fish in the lower Danube and the Danube delta: implications for ecotone connectivity. Hydrobiologia, 571: 51-61. doi: 10.1007/s10750-0060216-y

Stein III, W., Smith, P.W. \& Smith, G. 2014. The cast net: an overlooked sampling gear. Marine and Coastal Fisheries, 6: 12-19. doi: 10.1080/19425120.2013.864 737

Stewart, A.J.A., John, E.A. \& Hutchings, M.J. 2000. The world is heterogeneous: ecological consequences of living in a patchy environment. In: Hutchings, M.J., John, E.A. \& Stewart, A.J.A. (Eds.). The ecological consequences of environmental heterogeneity. Blackwell Science, Oxford, pp. 1-8.

Sundblad, G. \& Bergström, U. 2014. Shoreline development and degradation of coastal fish reproduction habitats. Ambio, 43(8): 1020-1028. doi: 10.1007/ s13280-014-0522-y

Tecchio, S., Rius, A.T., Dauvin, J.C., Lobry, J., Lasalle, G., Morin, J., Bacq, N., Cachera, M., Chaalali, A., Villanueva, M.C. \& Niquil, N. 2015. The mosaic of habitats of the Seine estuary: insights from food-web modelling and network analysis. Ecological Modelling, 312: 91-101. doi: 10.1016/j.ecolmodel. 2015.05.026

Velázquez-Velázquez, E., Vega-Cendejas, M.E. \& Navarro-Alberto, J. 2008. Spatial and temporal variation of fish assemblages in a coastal lagoon of the Biosphere Reserve La Encrucijada, Chiapas, Mexico. Revista de Biología Tropical, 56(2): 557-574. doi: 10.15517/RBT.V56I2.5608 
Verdiell-Cubedo, D., Torralva, M., Ruiz-Navarro, A. \& Oliva-Paterna, F.J. 2013. Fish assemblages in different littoral habitat types of a hypersaline coastal lagoon (Mar Menor, Mediterranean Sea). Italian Journal of Zoology, 80: 104-116. doi: 10.1080/ 11250003.2012. 686525

Warburton, K. 1978. Community structure, abundance and diversity of fish in a Mexican coastal lagoon system. Estuarine, Coastal and Shelf Science, 7(6): 497-519. doi: 10.1016/0302-3524(78)90061-0

Webster, I.T. 2011. Dynamic assessment of oceanic connectivity in a coastal lagoon-the Coorong, Australia. Journal of Coastal Research, 27(1): 131139. doi: 10.2112/JCOASTRES-D-10-00079.1

Whitfield, A.K. 1998. Biology and ecology of fishes in South African estuaries. Ichthyological Monographs 2. J.L.B. Smith Institute of Ichthyology, Grahamstown, 223 pp.

Received: 23 April 2019; Accepted: 5 July 2019
Wilkinson, T., Wiken, E., Bezaury-Creel, J., Hourigan, T., Agardy, T., Herrmann, H., Janishevsky, L., Madden, C., Morgan, L. \& Padilla, M. 2009. Marine ecoregions of North America. Commission of Environmental Cooperation, Montreal, 177 pp.

Yáñez-Arancibia, A., Lara-Domínguez, A.L., Chavance, P. \& Flores-Hernández, D. 1983. Environmental behavior of Términos Lagoon ecological system, Campeche, Mexico. Anales del Instituto de Ciencias del Mar y Limnología, 10(1): 137-176.

Yáñez-Arancibia, A., Lara-Domínguez, A.L., SánchezGil, P. \& Day, J.W. 2004. Interacciones ecológicas estuario-mar: marco conceptual para el manejo ambiental costero. In: Caso, M., Pisanty, I. \& Ezcurra, E. (Eds.). Diagnóstico ambiental del Golfo de México. Secretaría del Medio Ambiente y Recursos Naturales, Instituto Nacional de Ecología, México D.F., pp. 431490.

Zar, J.H. 2010. Biostatistical analysis. Prentice-Hall, New Jersey. 